\title{
Effect of Land Management on Soil Hydraulic Conductivity in Gidan Kwano, Niger State, Nigeria
}

\author{
John Jiya Musa1, Otuaro Ebierin Akpoebidimiyen², Pius Olufemi Olusegun Dada3, \\ Johnson Kayode Adewumi ${ }^{3}$, Yahaya Usman Gupa ${ }^{4}$ \\ ${ }^{1}$ Department of Agriculture and Bioresources Engineering, Federal University of Technology, Minna, Nigeria \\ ${ }^{2}$ Civil Engineering Department, Maritime University, Okerenkoko, Nigeria \\ ${ }^{3}$ Department of Agriculture and Bioresources Engineering, Federal University of Agriculture, Abeokuta, Nigeria \\ ${ }^{4}$ Department of Agricultural and Environmental Resource Engineering, University of Maiduguri, Maiduguri, Nigeria \\ Email: johnmusa@futminna.edu.ng
}

How to cite this paper: Musa, J. J., Akpoebidimiyen, O. E., Dada, P. O. O., Adewumi, J. K., \& Gupa, Y. U. (2021). Effect of Land Management on Soil Hydraulic Conductivity in Gidan Kwano, Niger State, Nigeria. Open Journal of Forestry, 11, 108-116.

https://doi.org/10.4236/ojf.2021.112008

Received: June 28, 2020

Accepted: April 9, 2021

Published: April 12, 2021

Copyright $\odot 2021$ by author(s) and Scientific Research Publishing Inc. This work is licensed under the Creative Commons Attribution International License (CC BY 4.0).

http://creativecommons.org/licenses/by/4.0/

\begin{abstract}
Hydraulic conductivity is one of the most important parameters for flow and transport related phenomena in soil and also a criterion for measuring soil ability to transfer water. There is concern arising from the suitability, efficiency and ease of the different measuring methods use under different land management practices. The purpose of this paper is to determine and evaluate soil hydraulic conductivity under different land management practices which include forest land (teak and Melina plantation), grassland and maize cultivated land using the constant head method. The measurement is at different depth of $0-15 \mathrm{~cm}, 15-25 \mathrm{~cm}, 25-50 \mathrm{~cm}, 50-75 \mathrm{~cm}$. The limited means of each land use were used to compare the result obtained through statistical means. All tests were carried out using SPSS at a significance level of 0.05. An ANOVA test was conducted to check if each of the land use is significantly different. The soil in forest zone (Teak plantation and Gmalina plantation) had a significantly high bulk density as $1.7533 \mathrm{~cm}^{-3}$ and 1.6967 $\mathrm{cm}^{-3}$ respectively at depth $50-75 \mathrm{~cm}$ compared to the low bulk density in the grass, maize cultivated land as $1.5000 \mathrm{~cm}^{-3}$ and $1.4833 \mathrm{~cm}^{-3}$ respectively at depth $50-75 \mathrm{~cm}$. However, soil hydraulic conductivity was significantly high in the grass site or soil at the surface with $2.8833 \mathrm{~cm} \cdot \mathrm{h}^{-1}$. Results obtained from the different land use serve as Knowledge of variability of soil that can assist in defining the best strategies for sustainable soil management through the provision of vital information for estimating soil susceptibility to erosion, hydrological modelling and efficient planning of irrigation projects.
\end{abstract}




\section{Keywords}

Bulk Density, Land Management Practices, Porosity, Soil Hydraulic

Conductivity

\section{Introduction}

The hydraulic conductivity of soil is an essential hydraulic property frequently used in hydrological modelling and water flow related studies in soils, such as irrigation and drainage system design and infiltration modelling; it is also a critical parameter for the monitoring of soil and water management (Tayfun, 2005). Knowledge of the rate of water permeability through various soil types is essential for determining the kind of plants to be grown, spacing, yield, managing soil-water systems and erosion control. Many methods have been developed over time for field and laboratory measurement for hydraulic conductivity. Unfortunately, these methods often yield substantially different results, as hydraulic conductivity is extremely sensitive to sample size, flow geometry and soil characteristics (Sarki, Mirjat, Asghar, Shafi, Kori, \& Qureshi, 2014). Research has shown that regardless of the land management practices, a small portion of soil can be transported by a large part of water flow, indicating that the spatial hydraulic characteristics of soils are highly variable (Ibrahim \& Aliyu, 2016). Knowledge of variability of soil physical properties can assist in defining the best strategies for sustainable soil management through the provision of vital information for estimating soil susceptibility to erosion, hydrological modelling and efficient planning of irrigation projects (Bagarello \& Sgroi, 2004).

Several studies have been conducted on soil hydraulic properties about tillage, and the results were contradictory. Depending on cultivation history, climate zone, and soil management practices, saturated and unsaturated hydraulic conductivity under no-till or minimum tillage can be higher or lower (Miller, Sweetland, Larney, \& Volkmar, 1998) than that under continuously tilled treatments, or not significantly different from that under continuously cultivated procedures (Bodhinayake, 2003). Change in land use from natural forest to crop cultivation modified the hydraulic properties of the surface soil resulting in an increased runoff/infiltration ratio (Leduc, Favreau, \& Schroeter, 2001). Land use change is a complex process shaped by human activity affected by ecological, economic, and social drivers, and capable of influencing a wide range of environmental and economic conditions (MacDonald, Crabtree, Wiesinger, Dax, Stamou, \& Fleury, 2000).

Understanding soil hydraulic conductivity is also essential for sound land management. Therefore, there is no single value that represents soil hydraulic conductivity because it varies in a wide range of circumstances and for all soil types and some of the specific problems that instigate the need of this kind of study which may be due to lack of suitability of the soil hydraulic conductivity 
and their acceptability in the study locations. Information relating to the hydraulic conductivity of the studied sites is a shortage.

This study is aimed at determining the hydraulic conductivity of soil under different land management practices and compare various results obtained from the study areas.

\section{Methodology}

\subsection{Study Area}

The host community of Federal University of Technology Minna Gidan Kwano is located along Minna-Bida road and is approximately $12 \mathrm{~km}$ from the state capital, Minna. Gidan Kwano lies between Latitudes $9^{\circ} 31^{\prime} \mathrm{N}$ and Longitudes $6^{\circ} 26^{\prime} \mathrm{E}$ with an estimated land mass of about eighteen thousand nine hundred hectares (10,000 ha). Teak plantation and Gmelina land is at latitudes and longitudes $9^{\circ} 31^{\prime} 1{ }^{\prime \prime} \mathrm{N}, 6^{\circ} 27^{\prime} 30^{\prime \prime} \mathrm{E}$ and $9^{\circ} 30^{\prime} 55^{\prime \prime} \mathrm{N}, 6^{\circ} 27^{\prime} 28^{\prime \prime} \mathrm{E}$ respectively while Grassland and Maize cultivated land is at $9^{\circ} 31^{\prime} 55^{\prime \prime} \mathrm{N}, 6^{\circ} 27^{\prime} 23^{\prime \prime} \mathrm{E}, 9^{\circ} 31^{\prime} 55^{\prime \prime} \mathrm{N}, 6^{\circ} 27^{\prime} 39^{\prime \prime} \mathrm{E}$ respectively. The site is bounded Northwards by the Western rail line from Lagos to the northern part of the country and the eastern side by the Minna-Bida Road and to the North-West by the Dagga hill and river Dagga (Musa, Adewu$\mathrm{mi}, \& \mathrm{Ohu}, 2012$ ). Niger State is located in southern guinea savannah forest zone of Nigeria. It is known to have two distinctive seasons of wet and dry. The wet season starts mainly from the month of April and ends during the month of October of the same year with a precipitation of $25.4 \mathrm{~mm}$, maximum and minimum temperature of $39^{\circ} \mathrm{C}$ and $22^{\circ} \mathrm{C}$. The wind speed of the study area is $10 \mathrm{~km} / \mathrm{h}$ while the average relative humidity is $60 \%$ (Musa, Akpoebidimiyen, Adewumi, Eze, Adesiji, \& Gupa, 2020).

Four locations were selected to perform the experiment, which includes forest sites (Teak and Gmelina plantations), grassland (fallow) and maize cultivated land. Measurement of soil hydraulic conductivity was determined at four depths of $0-15 \mathrm{~cm}, 15-25 \mathrm{~cm}, 25-50 \mathrm{~cm}$ and $50-75 \mathrm{~cm}$ for each of the study locations.

\subsection{Laboratory Analysis}

Particle size analyses were determined by the hydrometer method according to the procedure of Gee \& Or (2002) using sodium hexametaphosphate (Calgon) as a dispersant. Soil bulk densities were determined using the core method described by Fasinmirin \& Adesigbin (2011). Soil samples were taken from soil core at depths $0-15 \mathrm{~cm}, 15-25 \mathrm{~cm}, 25-50 \mathrm{~cm}$ and $50-75 \mathrm{~cm}$ on each location of the land use using ring cylinders with height $5.1 \mathrm{~cm}$ and diameter $5 \mathrm{~cm}(\mathrm{Ga}-$ briels \& Cornelis, 2008). Porosity was determined for each sample collected from the study area (Knutsson \& Morfeldt, 2002). The porosity of the soil was calculated from bulk density, and particle density was assumed as $2.65 \mathrm{mg} / \mathrm{m}^{3}$ (Suzuki, Ranert, \& Reichert. 2004). The hydraulic conductivity of soil was carried out according to the guideline of Akanegbu (2013). 


\subsection{Statistical Analysis}

A statistical test was carried out to compare the various results obtained from the different land management practices for the study areas using SPSS and tests are conducted at a significance level of 0.05 . For each of the location or different land management practices, the mean and standard deviation were calculated. A statistical test was conducted to check if each of the locations is significantly different. Marginal means of hydraulic conductivity, bulk density and porosity were used to compare the land use through multiple comparisons.

\section{Results and Discussion}

\subsection{Soil Aggregate}

The soil aggregate for the various study locations was determined and the result is presented in Table 1. It was observed that there was a gradual increment of the sand particle for $0-15 \mathrm{~cm}$ depth to a $50-75 \mathrm{~cm}$ depth which could be as a result of the decaying plant properties as this is within the root zone of crops.

Sandy soil is the most predominant soil in the study areas, and these are easily detached but hard to transport while the clayey soil is hard to separate but easily carried if finally separated. This reveals that the actual percentage of sand in any soil sample determines to a great extent the saturated hydraulic conductivity of that particular soil (Odumeke, 2014).

Table 1 presents the result of particle size composition of the collected soil samples. Teak plantation land shows a little variation in the percentages of sand,

Table 1. Soil textural classification of the forest land, Grassland and Maize cultivated land.

\begin{tabular}{|c|c|c|c|c|c|}
\hline Study location & Depth $(\mathrm{cm})$ & Sand (\%) & Silt (\%) & Clay (\%) & USDA Textural class \\
\hline \multirow{4}{*}{ Teak plantation } & $0-15$ & 60 & 12 & 28 & sandy clay loam \\
\hline & $15-25$ & 50 & 8 & 42 & sandy clay \\
\hline & $25-50$ & 65 & 10 & 25 & sandy clay loam \\
\hline & $50-75$ & 68 & 12 & 20 & sandy loam \\
\hline \multirow{4}{*}{ Gmalina plantation } & $0-15$ & 72 & 10 & 18 & sandy loam \\
\hline & $15-25$ & 62 & 18 & 20 & sandy clay loam \\
\hline & $25-50$ & 72 & 8 & 20 & sandy clay loam \\
\hline & $50-75$ & 65 & 17 & 18 & sandy clay \\
\hline \multirow{4}{*}{ Grass land } & $0-15$ & 65 & 15 & 20 & sandy clay loam \\
\hline & $15-25$ & 60 & 22 & 18 & sandy loam \\
\hline & $25-50$ & 58 & 20 & 22 & sandy loam \\
\hline & $50-75$ & 55 & 23 & 22 & sandy clay loam \\
\hline \multirow{4}{*}{ Maize cultivated land } & $0-15$ & 72 & 17 & 11 & sandy loam \\
\hline & $15-25$ & 70 & 17 & 13 & sandy loam \\
\hline & $25-50$ & 65 & 22 & 13 & sandy loam \\
\hline & $50-75$ & 60 & 18 & 22 & sandy clay loam \\
\hline
\end{tabular}


silt, and clay among the collected soil samples. According to the USDA classification system (Pachepsky \& Park, 2015), the soil samples collected at the 0 - 15 $\mathrm{cm}, 25-50 \mathrm{~cm}$ depth of teak plantation land are predominantly Sandy clay loam while those of $15-25 \mathrm{~cm}$ and $50-75 \mathrm{~cm}$ depths are sandy clay and sandy loam. The highest value of sand is $68 \%$ at depth $50-75 \mathrm{~cm}$ it also has the lowest percentage of clay at the same depth of $50-75 \mathrm{~cm}$ and this is in line with research work on manure teak plantation by Fernández-Moya, Alvarado, Forsythe, \& Marchamalo-Sacristán (2013). Table 1 shows that the gmalina plantation at depth $0-15 \mathrm{~cm}$ and $25-50 \mathrm{~cm}$ there is the same percentage of sand content which was also found in the studying of Fernández-Moya, Alvarado, Forsythe, \& Marchamalo-Sacristán (2013). From the results obtained from grassland, it shows that sand contents have the highest value of $65 \%$ of sand at depth $0-15$ $\mathrm{cm}$ and it has the lowest value of silt content as $15 \%$ in the study area of grass plantation. At depth $25-50 \mathrm{~cm}$ and $50-75 \mathrm{~cm}$ of grassland, the clay content remains the same. The results obtained from maize cultivated land shows that at depth $0-15 \mathrm{~cm}, 15-25 \mathrm{~cm}$, and $25-50$ the soil samples collected are predominantly sandy loam while that of depth $50-75 \mathrm{~cm}$ are sandy clay loam. The results obtained from soil textural classification throughout the land use mostly had a high percentage of sand particles. This high percentage of sand particles in this study area is similar to the works of Olorunfemi \& Fasinmirin (2012). They recorded a high rate of sand particles throughout their study but the values obtained from their study were observed to be lower when compared with values from this study location. This high percentage was associated with their study area, which is in a forest zone where they experience a high amount of rainfall compared to this study location.

\subsection{Statistical Analysis}

Table 2 shows that soil bulk density value for teak plantation land was observed to be highest at depth $50-75 \mathrm{~cm}$ with little porosity of $22.96 \%$ which means the soil is too compacted and there is no record of soil hydraulic conductivity at the depth. Also, the lowest soil bulk density is at the surface i.e. depth $0-15 \mathrm{~cm}$ which is almost in line with Ajibola, Oguntunde, \& Lawal (2018) and it has the highest hydraulic conductivity at the same depth. It was also observed that soil hydraulic conductivity decreases from the surface to the bottom i.e. from 0 - 15 $\mathrm{cm}$ to $50-75 \mathrm{~cm}$. These values from teak plantation site in the table were much lower than those found by Rubio iEsteve (2006).

Gmelina plantation shows that soil bulk density increases from the surface to the bottom, i.e. from $0-15 \mathrm{~cm}$ to $50-75 \mathrm{~cm}$. This is an indication that the soil is compacted down the soil profile for the study area. At $0-15$ and $15-25 \mathrm{~cm}$ depth, the bulk density is almost the same with a recorded porosity of $42.26 \%$ and $41.87 \%$ respectively. This is virtually in line with Ajibola, Oguntunde, \& Lawal (2018). The bulk density value obtained practically the same with one found by Uloma, Oyekachi, Torti, \& Amos (2013). The grassland in Table 2 shows that the bulk density at $50-75 \mathrm{~cm}$ depth was $1.50 \mathrm{~g} \cdot \mathrm{cm}^{-3}$ and is in line 
with a research work carried out by Uloma, Oyekachi, Torti, \& Amos (2013). The result obtained from the grassland show some variation down the profile and these changes down the pattern is also in line with the work of Rubio iEsteve (2006) due to these variations of soil bulk density, it can state that soil bulk density is one of the significant soil property that affects soil hydraulic conductivity. Soil hydraulic conductivity at the $0-15 \mathrm{~cm}$ record the highest value due to low soil bulk density at the profile. The results from maize cultivated land in Table 2 indicate that the soil bulk density at $15-25 \mathrm{~cm}$ and $25-50 \mathrm{~cm}$ is same and the soil hydraulic conductivity at that depth varies by a small value. At depth $50-75$ $\mathrm{cm}$ the soil hydraulic conductivity was lowest this could be as a result of high bulk density at the region. The highest amount of soil hydraulic conductivity from maize cultivated land in Table 2 was recorded at $0-15 \mathrm{~cm}$ depth. It is important to note that the physical properties of soil considered for this study are sand, silt and clay.

The saturated hydraulic conductivity varied at different locations. This confirms spatial variation of hydraulic conductivity as reported by other researchers (Rubio iEsteve, 2006). This variation was also further established by the statistical difference shown by other properties of soil determined which include porosity and bulk density. It was also noted that locations with the same soil textural class had different values of soil hydraulic conductivity. This is in line with the report of Ritzema (2006) that soils of same texture may have different soil hydraulic conductivity values due to differences in structure.

The subjected result to statistical analysis test in Table 3 shows that the hydraulic conductivity, bulk density and porosity of teak plantation site shows that

Table 2. Selected physical properties of the various study locations with their mean and deviation.

\begin{tabular}{ccccc}
\hline Location & & $\rho_{b}\left(\mathrm{~g} \cdot \mathrm{cm}^{-3}\right)$ & $P(\%)$ & $K_{\text {sat }}\left(\mathrm{cm} \cdot \mathrm{h}^{-1}\right)$ \\
\hline \multirow{3}{*}{ Teak plantation } & $0-15$ & $1.4067 \pm 0.01528$ & $46.92 \pm 0.576$ & $0.0006 \pm 0.00003$ \\
& $15-25$ & $1.5000 \pm 0.02000$ & $43.40 \pm 0.755$ & $0.0001 \pm 0.00002$ \\
& $25-50$ & $1.6200 \pm 0.02646$ & $38.87 \pm 0.996$ & $0.0005 \pm 0.00004$ \\
\hline \multirow{3}{*}{ Gmalina plantation } & $50-75$ & $1.7533 \pm 0.02517$ & $33.84 \pm 0.951$ & $0.000 \pm 0.00000$ \\
& $0-15$ & $1.5667 \pm 0.06658$ & $42.39 \pm 0.785$ & $0.0014 \pm 0.00040$ \\
& $15-25$ & $1.5867 \pm 0.10693$ & $42.01 \pm 0.433$ & $0.0014 \pm 0.00010$ \\
& $50-75$ & $1.6967 \pm 0.06506$ & $36.48 \pm 0.951$ & $0.0000 \pm 0.00000$ \\
\hline \multirow{2}{*}{ Grassland } & $0-15$ & $1.3000 \pm 0.01732$ & $50.94 \pm 0.652$ & $2.8833 \pm 0.02082$ \\
& $15-25$ & $1.3533 \pm 0.02082$ & $48.93 \pm 0.785$ & $1.4767 \pm 0.03215$ \\
& $25-50$ & $1.3533 \pm 0.03055$ & $48.93 \pm 1.155$ & $1.5033 \pm 0.01528$ \\
& $50-75$ & $1.5000 \pm 0.02000$ & $43.40 \pm 0.755$ & $1.3833 \pm 0.02082$ \\
\hline
\end{tabular}

Where $\rho_{b}=$ soil bulk density, $P=$ porosity, $K_{\text {sat }}=$ soil hydraulic conductivity. 
Table 3. Comparative levels of significance of the various physical properties for the different study location.

\begin{tabular}{|c|c|c|c|c|}
\hline Location & & Mean bulk density & Mean hydraulic conductivity & Mean porosity \\
\hline & GP & $-0.0192 \mathrm{~ns}$ & $-0.0005 n s$ & $0.73 \mathrm{~ns}$ \\
\hline \multirow[t]{3}{*}{$\mathrm{TP}$} & GS & $0.1933^{*}$ & $-0.0192^{*}$ & $-7.29^{*}$ \\
\hline & MS & $0.1983^{*}$ & $-1.1155^{\star}$ & $-0.748^{*}$ \\
\hline & $\mathrm{TP}$ & $0.0192 \mathrm{~ns}$ & $0.0005 \mathrm{~ns}$ & $0.73 \mathrm{~ns}$ \\
\hline \multirow[t]{3}{*}{ GP } & GS & $0.2125^{\star}$ & $-1.8109^{*}$ & $-8.02^{*}$ \\
\hline & MS & $0.2175^{\star}$ & $-1.1151^{\star}$ & $-8.21^{\star}$ \\
\hline & $\mathrm{TP}$ & $-0.1933^{\star}$ & $1.8114^{*}$ & $7.29^{\star}$ \\
\hline \multirow[t]{3}{*}{ GS } & GP & $-0.2125^{\star}$ & $1.8109^{*}$ & $8.02^{\star}$ \\
\hline & MS & $0.005 \mathrm{~ns}$ & $0.6958^{*}$ & $-0.19 \mathrm{~ns}$ \\
\hline & $\mathrm{TP}$ & $-0.1983^{\star}$ & $1.1155^{*}$ & $7.48^{\star}$ \\
\hline \multirow[t]{2}{*}{ MS } & GP & $-0.2175^{\star}$ & $1.1151^{\star}$ & $8.21^{\star}$ \\
\hline & GS & $-0.005 \mathrm{~ns}$ & $-0.6958^{\star}$ & $0.19 \mathrm{~ns}$ \\
\hline
\end{tabular}

* = The mean difference is significant at the 0.05 level, $\mathrm{ns}=$ the mean difference not significant at the 0.05 level and Where TP = Teak plantation site, GP = Gmelina plantation site, GS = Grass site, $\mathrm{MS}=$ cultivated land.

there is no significant difference between the teak plantation site and gmelina plantation site at 0.05 level. Though, there is a significant difference between teak plantation site and (grass, maize site), which means that bulk density, porosity and hydraulic conductivity does not affect the teak plantation and gmelina plantation site. Table 3 also shows that there is no significant difference $(<0.05)$ between grass and maize cultivated land for bulk density and porosity but has a significant difference in teak and gmelina plantation site.

\section{Conclusion}

The results obtained have shown that saturated hydraulic conductivity varied at different locations. This variation was also further confirmed by the statistical difference shown by other properties of soil determined which include porosity and bulk density. It was also noted that locations with the same soil textural class had different values of soil hydraulic conductivity.

The study further reveals the significant differences in the soil of four land uses in Gidan Kwano, Minna Nigeria. The soil hydraulic conductivity is strongly compared to bulk density and porosity. The soil in forest zone (Teak plantation and Gmalina plantation) had a significantly high bulk density as compared to the low bulk density in the grass, maize, beans and yam sites. However, soil hydraulic conductivity was significantly high in the grass site or soil. Soil hydraulic conductivity is highly dependent on soil texture, soil bulk density and porosity. Results show that soil bulk density and porosity, affect soil hydraulic conductivity of soils of the study areas. Results obtained from the different land use serve as Knowledge of variability of soil that can assist in defining the best strategies 
for sustainable soil management through the provision of vital information for estimating soil susceptibility to erosion, hydrological modelling and efficient planning of irrigation projects. Finally, the results of the experiment revealed that soil hydraulic conductivity varies considerably among land uses. Saturated hydraulic conductivity was higher in grasslands than in other land use. Improvement on this study could be made through the expansion of the area of studied and increasing the number of samples and measurements since soil is highly heterogeneous and tends to vary from point to point even at the same layer.

\section{Conflicts of Interest}

The authors declare no conflicts of interest regarding the publication of this paper.

\section{References}

Ajibola, Y. H., Oguntunde, P. G., \& Lawal, K. (2018). Land Use Effects on Soil Erodibility and Hydraulic Conductivity in Akure, Nigeria. African Journal of Agricultural Research, 13, 329-337. https://doi.org/10.5897/AJAR2017.12947

Akanegbu, J. O. (2013). Comparison of Different Methods of Measuring Hydraulic Conductivity in Drained Peat Soils using Drainmod as a Verification Tool. Master's Thesis. Oulu: University of Oulu.

Bagarello, V., \& Sgroi, A. (2004). Using the Single-Ring Infiltrometer Method to Detect Temporal Changes in Surface Soil Field-Saturated Hydraulic Conductivity. Soil and Tillage Research, 76, 13-24.

Bodhinayake, W. L. (2003). Characterization of Surface Soil Hydraulic Properties in Sloping Landscapes. Master's Thesis, Saskatoon: University of Saskatchewan.

Fasinmirin, J. T., \& Adesigbin, A. J. (2011). Soil Physical Properties and Hydraulic Conductivity of Compacted Sandy Clay Loam Planted with Maize Zee May. In Proceedings of the Environmental Management Conference, Abeokuta: Federal University of Agriculture.

Fernández-Moya, J., Alvarado, A., Forsythe, W., \& Marchamalo-Sacristán, M. (2013). Effect of Teak (Tectona grandis) Plantations on Hydraulic Conductivity and Porosity of Alfisols in Costa Rica. Journal of Tropical Forest Science, 25, 259-267.

Gabriels, D., \& Cornelis, W. (2008). Evaluation of Field Methods to Determine Hydraulic Properties of Stony Soils in Arid Zones of Chile. Gent: Faculteit bio-Ingenieurswetenschappen, Universiteit Gent.

Gee, G. W., \& Or, D. (2002). 2.4 Particle-Size Analysis. Methods of Soil Analysis: Part 4 Physical Methods, 5, 255-293.

Ibrahim, M. M., \& Aliyu, J. (2016). Comparison of Methods for Saturated Hydraulic Conductivity Determination: Field, Laboratory and Empirical Measurements. British Journal of Applied Science \& Technology, 15, 1-8.

https://doi.org/10.9734/BJAST/2016/24413

Knutsson, G., \& Morfeldt, C. O. (2002). Grundvatten, teori \& tillämpning (3rd ed., pp. 62-85). Stockholm: Svensk byggtjänst.

Leduc, C., Favreau, G., \& Schroeter, P. (2001). Long-Term Rise in a Sahelian Water-Table: The Continental Terminal in South-West Niger. Journal of Hydrology, 243, 
43-54. https://doi.org/10.1016/S0022-1694(00)00403-0

MacDonald, D., Crabtree, J. R., Wiesinger, G., Dax, T., Stamou, N., \& Fleury, P. (2000). Agricultural Abandonment in Mountain Areas of Europe: Environmental Consequences and Policy Response. Journal of Environmental Management, 59, 47-69. https://doi.org/10.1006/jema.1999.0335

Miller, J. J., Sweetland, N. J., Larney, F. J., \& Volkmar, K. M. (1998). Unsaturated Hydraulic Conductivity of Conventional and Conservation Tillage Soils in Southern Alberta. Canadian Journal of Soil Science, 78, 643-648. https://doi.org/10.4141/S97-061

Musa, J. J., Adewumi, J. K., \& Ohu, J. (2012). Comparing Developed Coefficients for Some Selected Soils of Gidan Kwano with Existing Values. Electronic Journal of Geotechnical and Engineering, 2999-3008.

Musa, J. J., Akpoebidimiyen, O. E., Adewumi, J. K., Eze, P. C., Adesiji, R., \& Gupa, Y. U. (2020). Influence of Soil Bulk Density and Porosity on Soil Hydraulic Conductivities for Selected Land Management Practice in North-Central Nigeria. International Journal of Agricultural and Environmental Sciences, 5, 1-7.

Odumeke, G. (2014). Determination of Saturated Hydraulic Conductivity of Lower coal Measure Geological Formation of Owukpa Ogbadibo LGA, Benue State, Nigeria. Makurdi: Federal University of Agriculture, $50 \mathrm{p}$.

Olorunfemi, I. E., \& Fasinmirin, J. T. (2012). Hydraulic Conductivity and Infiltration of Soil of Tropical Rain Forest Climate of Nigeria. COLERM Proceedings, 2, 396-412.

Pachepsky, Y., \& Park, Y. (2015). Saturated Hydraulic Conductivity of US Soils Grouped According to Textural Class and Bulk Density. Soil Science Society of America Journal, 79, 1094-1100. https://doi.org/10.2136/sssaj2015.02.0067

Ritzema, H. P. (2006). Drainage Principles and Applications (pp. 283-294). Wageningen: International Institute for Land Reclamation and Improvement.

Rubio iEsteve, C. M. (2006). Hidrodinámica de Los Suenos de unárea de montaña media mediterráneasometida a Cambios de uso y cubierta. Universitat Autònoma de Barcelona, $195 \mathrm{p}$.

Sarki, A., Mirjat, M., Asghar, A., Shafi, M., Kori, M., \& Qureshi, L. (2014). Determination of Saturated Hydraulic Conductivity of Different Soil Texture Materials. Determination of Saturated Hydraulic Conductivity of Different Soil Texture Materials, 7, 56-62.

Suzuki, L. E. A., Ranert, D. J., \& Reichert. J. M. (2004). Degree of Compactness for Tillage Soils. Reference Bulk Density and Effects on Soil Physical Properties and Soya Bean Yield.

Tayfun, A. (2005). Saturated Hydraulic Conductivity: A Study of Path Analysis in Clayey Soils. Atatürk Üniversitesi Ziraat Fakültesi Dergisi, 36, 23-25.

Uloma, A. R., Oyekachi, C. T., Torti, E. K., \& Amos, U. (2013). Infiltration Characteristics of Some Selected Schools in Aba, Nigeria. Archives of Applied Science Research, 5, $11-15$. 